\title{
Report \\ The World Social Forum \\ on Migrations 2012 \\ Consolidating efforts towards \\ an equitable society
}

Shirlita Africa Espinosa

From the back alleys of Madrid to the financial capital of Singapore, the migration of peoples either to flee persecution or to pursue a high-stakes transnational job is a global phenomenon. One may even say that the one permanent presence these days is a temporary migrant. The mobility of workers - and the mobility that characterizes the social world in which they live-has always had an economic interpretation manifesting in the antagonism of locals against labor migrants. The issue of migration and the attendant discourses of citizenship, social cohesion, population, resource sharing, employment, criminality, and cultural differences, to mention a few, are a common specter often raised for political maneuvering. To use the migrant subject as a scapegoat for sundry social and economic ills of the "host" society-a term that perpetuates the stereotype of the migrant as parasitical, thus, creating a fitting formula for those who hold power-is integral to the production of their subjectivity as an unwanted sector of a society. Nevertheless, the centrality of migration today in the creation of wealth in advanced economies is very much tied to the role that migrants play in the development strategies of their own nations. Through the billions of dollars transferred through remittances, migration is regarded as the vehicle of development for countries in the South. But if exporting cheap and temporary labor remains inexpensive as it continues to support the growth of industrialized countries both in the manufacturing and service sectors, including the domestic and affective spheres of the home, then how does migration specifically drive the development of sending countries?

This question was at the heart of the recently concluded World Social Forum on Migrations (WSFM) held in Manila, Philippines. A sum- 
mit attended by hundreds of scholars, activists, labor organizers, trade unionists, students, workers, and migrants from more than 50 countries, the fifth WSFM held on 26-30 November, 2012 was a successful event in so far as it consolidated the efforts made by migrants and social movement actors to advance migrant rights. Held for the first time in Asia, after being hosted in Porto Alegre, Brazil, in 2005, Rivas Vaciamadrid, Spain, in 2006 and 2008, and Quito, Ecuador, in 2010, the Manila summit was well attended by delegates from mainland Asia and the Pacific Rim. Plenary discussions and poster session discussions were translated into Spanish and French for the comrades from Europe. The event started with a short march of delegates and culminated in a march and rally on the historic Mendiola Avenue in Manila on Andrés Bonifacio day to celebrate the legacy of the Filipino hero of the working class. Given that 10 million Filipino migrants support the structures of an income-strapped government, the so-called bagong bayani (modern day heroes) are this "new," surplusproducing working class. The Philippines is often considered a "model" country of best practices and effective policy making on exporting labor, and the delegates had a chance to visit agencies like the Philippine Overseas Employment Administration (POEA), the Commission on Filipinos Overseas (CFO), and the National Reintegration Center for Overseas Filipino Workers (NRCO) on the third day of summit. These state institutions serve to remind us how deeply entrenched labor exportation is as a national development policy which, in turn, raises the question whether migration will remain unabated in the future. WSFM tacitly asks if a future where citizens would rather not migrate is possible, suggesting that if "another world is possible," it should be one wherein people move freely rather than forcibly.

The overall theme of this year's WSFM was the search for alternatives to development regarding migration with a specific focus on global parliamentary participation. The four subthemes were: 1 ) crisis, critiques, and consequences of global migration; 2) migrants' rights are human rights; 3) re-imagining migration: proposing alternatives, exploring models; and 4) resistance, organization, and action. These four areas of discourse are nonetheless anchored to the one thrust to advance migrant workers' rights wherein workers do not lose their human rights as they cross national borders. Three plenary sessions were dedicated to the four subthemes. Panelists included progressive scholars who shared their expert analyses questioning the perceived relations between migration and development. Prof. Raul Delgado Wise of the International Migration and Development Network emphasized that today's labor migration is forced migration as people are literally "expelled" from their land and source of livelihood. 
This phenomenon is marked by the deepening of unequal development, of "a new international division of labor" and its new modalities. Prof. Wise hopes that the forum in Manila will be "a turning point" in the history of the WSFM as now is the time to truly counter the ravages caused by the "precarization of labor markets." More than 1.2 billion workers were living in poverty before the global financial crisis and 620 million in extreme poverty (Wirth, 2009, p. 2).

The keynote speaker, Walden Bello, founder of the Focus on the Global South and now a member of the Philippine parliament, drew attention in his capacity as chairperson of the Committee on Migrant Workers Affairs in the parliament to the many cases of abuse of Filipino domestic helpers, particularly in the Middle East where their basic human rights are not recognized. Bello linked cases of abuse to the broader problem of labor trafficking - the "new slave trade" - as the manifest contradiction of global capitalism's accumulation of great wealth today through the exploitation of migrant labor. Labor exportation, like drug and slave trades, is "big business" and institutionalized, according to Bello, where recruiters, governments, the US Department of Defense, and service providers such as Aramark are implicated in the trafficking of cheap labor. This macroeconomic strategy is core to neoliberalism's extractive appropriation whose consequences include the gutting of social welfare, the pauperization of the peasantry, the worsening inequality of wealth, and hunger. Bello called for an "end to this modern-day slavery" through a common front among sending countries in advancing migrant rights while reforming their domestic economies to stand against the onslaught of neoliberal policies.

Activists William Gois of Migrant Forum Asia and Peruvian Edda Pando of ARCI Italy, in separate sessions, called for unity among migrant activists. Gois asked how people who work for migrant advocacy could achieve a deeper solidarity. He posited that "we in the civil society should be critical of ourselves." Pando's related call for unity is, on the one hand, based on her disillusionment on the prevailing disunity and rivalry among migrant groups. "I am tired of resisting. We should start imagining" (translated from Spanish), claimed Pando, for the movement to advance. Oscar Cachon of the National Alliance of Latin American and Caribbean Communities, on the other hand, added that calls for unity are "not realistic" in a field with so many actors; instead of unity, he seeks collaboration. The issue of unity or, should I say, the "problem" of forging unity takes a central position in solidarity movements. As exemplified by the concerns above, the challenge of a united front can either spell the success of an initiative or its breakdown. Should there only be temporary alliances and strategic collaborations? Would this avoid the need for a kind of centralized organization of migrant activists to maintain "order" and 
police agenda setting? This challenge is evident in the dynamics between Filipino organizations in Europe. A session by the Center for Migrant Advocacy explored what alternatives there are in building a movement. Ellene Sana, who chaired the session, raised the point of the extent and efficiency of "cross-border solidarity and alliances" in Europe given the overlapping advocacy efforts of the groups. Filipino organizers based in France, the Netherlands, Italy, and Switzerland were present to discuss their groups' accomplishments. From where I stood, there was an undeniable tension in the room, signaling a rivalry amongst these groups, and there appears to be a tug-of-war regarding who did what, who did it first, or who owns this discourse. It was apparent that a kind of territorialism can thwart or break any possibility of unity to pursue goals or projects. Because Filipino organizations in Europe struggle to forge a level of solidarity, the possibility of forming alliances with other migrant groups such as Africans, Asians, and other marginalized groups to strengthen solidarity against the anti-migrant right-wing parties mushrooming all over the EU was, therefore, sidelined. I believe that challenge of a "united front" need not be about temporary collaborations that reek of the opportunism they somehow imply, nor should it encourage a rigidity characteristic of a vertically oriented hierarchy simply to maintain "unity." The quest, or should we say, panic, for a united front is a beautiful chimera, a project programmed to fail for the unattainable status it demands from its actors. Unity as a chimera, however, works because of its fallibility. Because it is unobtainable, it repeatedly teaches social actors to ask themselves what fails and what succeeds. Every time a call for unity is bogged down it is an opportunity for self-criticism and evaluation. So while the question of unity is a narrative of collapse and regret, it may not necessarily be a failed exercise. The "uses of error" for activists to exploit and learn from underlie the logic why activists persist in chasing after "unity."

Another sector that was given a platform in the forum is that of migrant domestic workers. Given the recent ratification of the International Labor Organization (ILO) Convention 189, which is the first international instrument on domestic workers, by Uruguay, Philippines and then Mauritius, there were discussions on how to promote the ratification and enforcement of ILO 189 in more countries. The objectives of the Convention are to protect the human rights of domestic workers by promoting domestic work as work that deserves decent pay, safe working conditions, and a regular eight-hour workday like other jobs. Domestic workers who cross borders to perform dirty, dangerous, and demeaning jobs are more susceptible to abuse. ILO 189 is one clear success that could further bring about better working conditions for domestic workers who are mostly women. In India, the campaign to organize domestic workers into a trade 
union has been effective to re-characterize work in the private sphere as "Decent Work" protected by law, an issue on which the ILO has been vigorously working. ${ }^{1}$ Unionism is one possible avenue of improvement that migrant domestic workers can pursue. Solid collective action enforceable as law should also secure women's control of their reproductive capacity. Women's bodies are their own and they should exercise full sovereignty over their bodies. Because they are raped and subject to sexualized molestation, their bodies are doubly vulnerable and colonized: first as women and second as workers.

The fight for gender justice in the context of the feminization of migration is anchored in the broader struggle against an elitist economic system through a financial, labor, and trade order that feeds on cheap, expendable, and migratory labor. Gender inequality and patriarchal structures that buttress this system that renders today's labor as precarious are tied to a global class warfare. A path towards gender justice, for migrant and non-migrant women alike, is, therefore, integral and not secondary to the campaigns of social movements today to achieve economic justice. Moreover, there is a call to end machismo in social movements and activism. For gender justice to advance, the masculinity of activism is an immediate concern that must be addressed. If within the movement, patriarchy is present even if subtle, then the struggle for gender justice will be internally undermined. The call for "best practices" within social movements is also reflected in the transnationalization of solidarity. The session organized by Global Migration Policy Associates emphasized the need to register resistance on a wider scale, and create more space for advocacy and organizing by migrants. William Gois of Migrant Forum Asia advanced another argument that goes beyond the challenge of transnationalizing activism, which is a mainstream practice today. Rightly, he posed a question to activists present in the room: "How ready are we to accept that 'migrant rights are human rights'?" Currently, most responses from the ground are what Gois called "service-oriented" action rather than the more strategic "justice-oriented," human rights-focused responses. A "structural kind of change" is needed, said Gois. One imagines that the structural changes Gois referred to would have to accommodate a more gendered interpretation of a justice-oriented framework of activism. The WSFM, in many ways, induces the kind of structural changes that Gois identified as key in advancing migrant rights. The dialectical exchanges between actors during the forum precipitate creative and critical ideas that could open new areas of inquiry in migration and initiate dialogues between sectors. An example of this was evident in a session on women and migration.

A "Women's Caucus" was formed during the week-long summit, where feminists and women's groups were invited to formulate strategies 
to address the most pressing issues regarding women migrants. In light of what is termed the "feminization of migration" and the "feminization of poverty," the gendered aspect of migration is a priority that needs attention, not only in WSFM but also within the discourse of migration and development. This claim was echoed in a poster session headed by Dr. Sylvia Claudio of the University of the Philippines. In the small-group workshop composed of feminists, lawyers, advocates, nuns, marriage migrants, and an academic, hailing from South Korea, Japan, the Philippines and Australia, the privileging of migration as labor sold in the market in the wider discourse was questioned. In particular, they posited that the apparent lack of discussion of marriage migrants within the WSFM is symptomatic of a problem that is rooted in gender inequality. As such, they felt that WSFM had been masculinist in this aspect. Noting that the members of the group were with NGOs affiliated with women's organizations or studied international marriage migration in countries where there has been a high incidence of "bride" sponsorship, they raised the point why circular labor migration, remittances, and diaspora philanthropy are directly linked to the development of sending countries but not to international marriage migration. While the number of sponsored brides is significantly less than that of female labor migrants, and they are perceived to enjoy an easier and safer path to migration (thus, a perception that brides jump the queue of immigration), they claim that the "communities" built by brides in their host countries and the contributions they make either through remittances, charity, sponsorship of family members, and other civic duties in the sending countries merit a special attention and study that connects marriage migration to development. The kind of "migration management" extended to promote labor migration should be equally given to women whose reproductive, domestic, and affective labors, while not quantifiable in the market, are appropriated for private (thus, indirectly, for public) enrichment. The group put forth the recommendation that the next WSFM give space to this particularly gendered discourse. An idea as innovative and important as the contribution of international marriage migrants to development is worth the attention of migration experts and feminist theorists alike.

The WSFM, considered as the alternative to UN's Global Forum on Migration and Development (GFMD), responds to what is perceived as GFMD's long-term program to hijack labor migration for capitalist expansion. Held in Mauritius this year just a few days before the WSFM forum in Manila, the GFMD, launched in 2006 during the UN's High Level Dialogue on Migration and Development, is an platform for "dialogues and partnerships" to maximize the benefits of migration for development. Operating within the ambit of World Bank's (2011) and the OECD's (OECD, 
2012, p. 9-12) twinning of migration and development, sending nations are compelled to align their national poverty reduction programs vis-àvis the framework of GFMD. However, the UN forum remains a "voluntary, non-binding and informal consultative process" (GFMD, 2012) of member states and observers, and civil society organizations doubt the effectiveness of GFMD's recommendations and their ability to be enforced on a global scale. The 2008 GFMD called for "develop[ing] a compendium of best practices at national, regional and international levels on protecting migrants" but immigration and labor laws may counter the identified "best practices" if they go against issues of national sovereignty and security (GMFD, 2008). GMFD's ability to shape the normative discourse around "regulating" migration could tilt the balance in favor of developed countries, in their search for skilled labor, further encouraging sending countries to become more reliant on remittances, spurring the exportation of labor (Asia Pacific Mission for Migrants, 2012). It has been pointed out that previous GFMD consultations have focused on temporary labor migration that imports cheap labor without the inconveniences of making those workers permanent residents and looking after their long-term welfare. The 2012 GFMD in Mauritius gives, for the first time, the forum a "regional outlook" where African nations' "best practices" are showcased; for instance, the implementation of the African Union's Migration Policy Framework within which the African Institute for Remittances (AIR) forms part (Kaloko, 2012).

WSFM maintains the position that remittances are not the path towards equitable development for people in the South. The "remittances myth" holds true for nations such as Mexico whose highly skilled professionals' training, educational investment, and social reproduction outweigh the cost of remittances in the US-Mexico corridor, according to Prof. Wise. Global migration today needs to be reformulated along the lines of a rights-based governance rather than following the demands of a labor market that is not free at all but monopolistic. Finally, WSFM calls for continued efforts to develop a Southern perspective on migration and a more aggressive campaign as global capitalism becomes more sophisticated in its operations. A parallel event outside of the WSFM, the International Migrants' Tribunal on the GFMD, held at the University of the Philippines and sponsored by International Migration Alliance and others, conducted a mock trial of GFMD. It was declared guilty as a tool for the appropriation of migrant labor for global capitalist expansion that will further the immiseration of peoples from the South.

There were several sessions in the WSFM dedicated to the Palestinian issues of dispossession, displacement, and right of return. A strong delegation representing different sectors of the Palestinian cause used the 
platform to campaign against the ongoing and intensifying occupation by Israel, and more urgently, to put a stop to the atrocities committed against the people in Gaza and the West Bank. During the march and rally in which WSFM delegates were joined by multisectoral groups composed of workers, women, the urban poor, the peasantry, and others, two Palestinian women delivered their message of solidarity. They celebrated the recent declaration of Palestine as a "non-member state" of the UN. The Palestinian representatives thanked the Filipino people for their support and the Philippine government for voting "yes" at the UN and condemned the US for justifying continued Israeli rule.

While it may be difficult to quantify the successes of the 2012 WSFM immediately, imagining its long-term contributions towards the advancement of migration discourse and advocacy is not. The Forum stands on the accomplishments of previous meetings, the tenacity of the people behind WSFM, and the zeal of the participants to advance a common advocacy, and these are evident in the wide scope of migration-related issues covered in the recent WSFM. Because the success of social movements is hinged on the cumulative efforts of its actors over a period of time, an institutionalized congress where ideas and debates are provided a platform gives birth to the conduct of the battles fought on the ground. The WFSM, for example, has already set the outlines of a counterdiscourse against GFMD's new program of strategies to link migration to development. The outcome of these congresses will not only define how the flows of people towards their search for livelihood or away from the violence of poverty are managed but also the parameters by which the many orders of understanding mobility will be set. My participation in the WSFM as an academic was not only professionally enriching in the way it opened to me a plethora of topics with which to critically engage my own scholarship, but it also brought the realization, in a personal way, of how my life and social world are very much shaped by all the movement around me and my own mobility's contribution to the connected sociality we all create. Most people's lives today - as a migrant, a child of a migrant, or a person dreaming of becoming a migrant-are, in a manner of speaking, inspired by the very foundation of struggle by which WSFM stands.

SHIRLITA AFRICA ESPINOSA currently holds a postdoctoral research fellowship at the University of Luxembourg under the Fonds National de la Recherche Luxembourg and the Marie-Curie Scheme working on the topic of diaspora philanthropy and development in three European countries. She received her PhD from the University of Sydney in Australia, and was supported by the Ford International Fellowship, USA, from 2009 to 2011. 


\section{NOTES}

1. The UN World Summit in 2005 identified Decent Work to be part of 'relevant national and international policies' because 'work is a source of personal dignity, family stability, peace in the community, democracies that deliver for people, and economic growth that expands opportunities for productive jobs and enterprise development' (ILO, 2006).

\section{REFERENCES}

Asia Pacific Mission for Migrants. (2012). Relevance, Nexus E Prospects: An Impact Study of the GFMD and its Migration Paradigm. Hong Kong: Asia Pacific Mission for Migrants.

GMFD. (2012). International Migration and Development at the United Nations, http://www.gfmd.org.

GFMD. (2008). Manila Outcomes: Selected Issues Relating to Policy Coherence, http://www.gfmd.org.

ILO. (2006). Facts on Decent Work. Geneva: ILO.

Kaloko. M.S. (2012). Statement at the Global Forum on Migration and Development. http://www.gfmd.org

OECD. (2005). Executive Summary: Migration, Remittances and Development in OECD Migration, Remittances and Development. Paris: OECD Publishing.

Wirth, L. (2009). Editorial. Decent Work for All: Quarterly Newsletter of the ILO in the Philippines, 7 (2), 2.

World Bank. (2011). Migration and Remittances Factbook 2011. $2^{\text {nd }}$ edition. Washington, DC: International Bank for Reconstruction and Development. 